\title{
Treatment Adherence in Bipolar Disorder
}

\author{
Haluk A. Savaș ${ }^{1}$, Ahmet Unal², Osman Vırıt ${ }^{3}$
}

ÖZET:

\section{iki uçlu bozukluk'ta tedavi uyumu}

Amaç: iki Uçlu Bozukluk (iUB), kronik seyri nedeniyle sürdürüm tedavisini gerektiren ve bu yüzden etkin tedavi için yüksek düzeyde hasta uyumunun zorunlu oldug̃u bir hastalıktır. IUU'de tedaviye uyumsuzluk, nüks ve yinelemenin ana sebebi olarak düsünülür. Bu calısmada, en az bir yıl öncesinden psikiyatri poliklinigininde kaydı́ olan ötimik iki uçlu hastalarda: son bir ayda ilac tedavisine uyum düzeyinin, uyumu etkileyen sosyodemografik, klinik özelliklerin ve son bir yıl içerisindeki takip muayene sayıları ile tedavi uyumu arasındaki iliş̧kinin araștıııımasını amaçladık.

Yöntem: Malatya Devlet Hastanesi Psikiyatri Polikliāi'ne bašvuran 18 yașından büyük, DSM-IV'e göre iUB tanısı konulmuș ve en az bir yııldır bu tanı ile poliklinik takibinde olan ötimik, 147 hasta çalıșmaya alındı. 01-28 Șubat 2011 tarihleri arasında takip muayenesine gelen hastaların eșzamanlı olarak hastane bilgisayar kayıtlarına bakıldı. 01 Subat 2010'dan itibaren bilgisayar kaydı olanlar çalışmaya alındı ve kaç defa takip muayenesine geldiḡi kayıtlardan tespit edildi. Çalısmaya aldığımız hastaların demografik deg̃ișkenlerini, klinik özelliklerini, hastalığı ve tedavisi ile ilgili tutumlarını iceren bilgiler hazırladıōımız Veri Toplama Formu'na kaydedildi. Hastalar, son bir ay icerisinde ilac kullanmadig̃ı ya da düzensiz kullandiğı gün sayıssı $7^{\prime}$ den az olanlar tedaviye uyumlu, $7^{7}$ den fazla olanlar tedaviye uyumsuz olarak iki gruba ayrildi. Verilerin istatistiksel analizi SPSS 16.0 ile yapıldı. Tedaviye uyumlu ve uyumsuz grupların verileri karsilastirıld.

Bulgular: Hastaların, $108^{\prime} \mathrm{i}(\% 73.5)$ tedaviye uyumlu, 39'u (\%26.5) tedaviye uyumsuzdu. Eğitim düzeyi (8 yıl temel alındı) uyumlu grupta daha yüksekti $(p<0.001)$. Uyumlu grupta hastanede yatıs oranı, uyumsuz gruba göre daha düșüktü $(p<0.05)$. Uyumlu grupta son bir yılda takip muayenelerine devam etme oranı $(p<0.001)$ ve hastalıg̃ına karșı içgörü oranı daha yüksekti $(p<0.001)$. Her iki grup arasında şu anda kullandig̃ı ilaç veya ilaç kombinasyonları açısından fark yoktu $(p>0.05)$. Uyumlu grup, hastalığı ve tedavisi hakkında uyumsuz gruba göre daha fazla bilgilendirildiğini düșünüyordu $(p<0.001)$. Uyumsuz grupta, tedaviden fayda görmediḡini düșünerek $(p<0.05)$ ve iyilestiḡini düșünerek ilacı bırakma oranı daha yüksekti $(p<0.001)$. Ayrıca, iyileștiḡini düsünerek tedaviyi bırakma oranı tedaviden fayda görmediḡini düsünerek ilac bırakma oranına göre daha yüksekti $\left(p=0.04, \chi^{2}=8.64\right)$. ilaç kullanmaktan hoșnutsuz olma uyumsuz grupta daha yüksekti $(p<0.05)$

Sonuç: Bu araștırmada, düșük eg̃itim düzeyi, hastalıkla ilgili yetersiz bilgilendiḡini düșünme, içgörü eksikliäi, tedaviden hoșnutsuz olma gibi veriler tedaviye uyumsuz grupta daha fazla bulundu. Ayrica, tedaviye devam etmemenin en önemli sebebinin iyileștiğini düșünerek ilacı bırakma oldug̃u saptandı.

Anahtar sözcükler: îki uçlu bozukluk, tedavi uyumu, tedavi uyumsuzlug̃u

Journal of Mood Disorders 2011;1(3):95-102

\section{ABSTRACT:}

Treatment adherence in bipolar disorder

Purpose: A high level of treatment adherence is essential in patients with bipolar disorder for effective treatment, due to chronic progressive nature of the illness requiring maintenance treatment. Treatment nonadherence in individuals with bipolar disorder is the main reason for relapse and recurrence. The purpose of this study is to investigate the relationship between treatment adherence and the level of medication treatment adherence in the last month, socio-demographic and clini characteristics affecting adherence, and the number of follow-up examinations within the last year in euthymic bipolar patients who registered at a psychiatry outpatient clinic at least a year ago. Method: The sample group of this study comprised of 147 euthymic patients, aged over 18, who visited the Psychiatry Outpatient Clinic of Malatya State Hospital, and diagnosed with a Bipolar Disorder in accordance with DSM-IV and had been monitored at the clinic for at least a year because of this diagnosis. The hospital records were examined simultaneously for patients attending their follow-up examinations between 02.01.2011 and 02.28.2011. The patients, who had computerized records as of February 01, 2010, were included in this study and their number of follow-up examinations was obtained from hospital records. The information regarding participating patients' demographic variables, clinical properties, and their attitude towards their illness and treatment were recorded in the Data Gathering Form. The patients were categorized in two groups; those that had taken their medication or taken it irregularly for less than seven days within the last month were categorized as "treatment adherent," and those that had not taken their medication or taken it irregularly for more than seven days within the last month were categorized as "treatment nonadherent." SPSS 16.0 was used for the statistical data analysis. The data of treatment adherent group was compared to the data of treatment nonadherent group.

Results: $108(73.5 \%)$ patients were treatment adherent, while $39(26.5 \%)$ patients were treatment nonadherent. The leve of education (based on 8 years) was higher in the treatment adherent group $(p<0.001)$. The rate of hospitalization was lower in the treatment adherent group in comparison to the treatment nonadherent group $(p<0.05)$. The rate of attending to follow-up examinations within the last year $(t=-5.42)$ and the level of insight towards their illness was higher in the treatment adherent group $(p<0.001)$. There was no difference between the two groups in terms of their present medication or drug combinations $(p>0.05)$. The treatment adherent group believed that they were more informed about their illness and treatment in comparison to the nonadherent group $(p<0.001)$ The treatment nonadherent group believed that treatment had no effect on their disorder more than the treatment adheren group $(p<0.05)$; the rate of disregarding medication because they thought they had recovered was higher in the treatment nonadherent group in comparison to the treatment adherent group $(p<0.001)$. The rate of abandoning treatment, because of thinking that they had recovered, was higher in comparison to the rate of not taking medication, because they thought the treatment was not effective $\left(p=0.04, \chi^{2}=8.64\right)$. The number of patients, who were discontent about taking medication, was higher in the treatment nonadherent group $(p<0.05)$.

Conclusion: In this study, some characteristics such as a lowe education level, thinking that they had inadequate information regarding their illness, lack of insight, and dissatisfaction with treatment, were significantly higher in the treatment nonadherent group. The most common reason behind discontinued treatment was that individuals believed that they had recovered from their disorder and discontinued their medication(s).

Key words: Pregnancy, antidepressant safety, teratogenicity, untreated depression

Journal of Mood Disorders 2011;1(3):95-102
'MD, Professor, Gaziantep University, Faculty of Medicine, Department of Psychiatry, Gaziantep-Turkey

${ }^{2} \mathrm{MD}$, Assistant Professor, Gaziantep University, Faculty of Medicine, Department of Psychiatry, Gaziantep-Turkey ${ }^{3} \mathrm{MD}$, Associate Professor, Gaziantep University, Faculty of Medicine, Department of Psychiatry, Gaziantep-Turkey

Yazısma Adresi / Address reprint requests to: Ahmet Unal, MD, Assistant Professor, Gaziantep University, Faculty of Medicine, Department of Psychiatry, Gaziantep-Turkey

Telefon / Phone: +90-342-360-6060/76363

Faks / Fax: +90-342-360-3928

Elektronik posta adresi / E-mail address: drahmetunal@hotmail.com

Kabul tarihi / Date of acceptance: 27 Ag̃ustos 2011 / August 27, 2011

Bag̃ıntı beyanı:

H.A.S., A.U., O.V.: Yazarlar bu makale ile ilgili olarak herhangi bir çıar çatıșması bildirmemișlerdir.

Declaration of interest:

H.A.S., A.U., O.V.: The authors reported no conflict of interest related to this article. 


\section{INTRODUCTION}

Bipolar Disorder (BD) is a degenerative and chronic illness. In the long term, BD may lead to high morbidity, comorbid mental and physical illnesses, hospitalization, loss of competence, substance abuse, and increased death due to suicides (1). The recurrence levels are significantly high. Without medication treatment, relapse is over $90 \%$ in the 18 months following the manic episodes, and $70 \%$ following the depressive episodes. Even if patients are treated with drugs, the 5 -year relapse rate exceeds $70 \%$ (2).

$\mathrm{BD}$ is an illness that requires a high level of treatment adherence in order to achieve effective treatment as it is a chronic illness requiring continuous treatment. The adherence can be defined as the patient accepting and following recommendations regarding their illness and its treatment. This definition does not just refer to "prescribed drug use," but is a broad definition and also refers to "the treatment adherence, at behavior level, of the patient to all recommendations made by the clinician" (3). The Word Health Organization (WHO) defines adherence as "the adherence level of behavior displayed by an individual that is receiving treatment, has a special diet, and/or is making changes in their life style in accordance with recommendations made by a health professional" (4). Nonadherence to treatment in studies ranges between $20 \%$ and $70 \%$; the average nonadherence is $40 \%(6,7)$. This nonadherence is related to unsuccessful treatment results, increased relapse rates $(8,9)$, rehospitalization $(9,10)$, suicidal behavior, and increased care costs. Treatment nonadherence to $\mathrm{BD}$ is thought to be the main reason of relapse and recurrence $(2,11)$. Treatment adherence in a bipolar population is a complex case that is affected by factors related to the health system, individuals that care for the patients, the patient themselves, and numerous illnesses $(5,12)$. A relationship has been identified between treatment nonadherence and demographic variables of patients such as age, gender, and ethnicity and illnessspecific characteristics such as the severity of the illness or other additional illnesses. Additionally, some studies report that treatment risks, personal differences in understanding the requirements of medical treatment, unbearable side effects of drugs, complicated drug applications, insufficient knowledge regarding the illness (13), the fear of being stigmatized (9), lack of insight (14), low education level, personality disorders, and abusing additional substances associated with treatment are all factors that have an adverse effect on treatment adherence $(2,15)$. The attitude of individuals that suffer from a severe mental illness towards their illness and treatment play an extremely important role in determining the treatment adherence of individuals.

Treatment nonadherence is the most important restriction in transforming treatment success, proven in research studies, into an effective factor in clinical practice (6). The nonadherence rate is still high, regardless of numerous improvements in medications (16). The patient's treatment adherence is extremely important in obtaining successful long-term results in BD. Unfortunately, not many studies have focused on this subject. There are no studies in our country that illustrate the adherence rate. There is only one paper about the attitude of patients.

The purpose of this study is to investigate the treatment adherence of euthymic bipolar patients, who registered in a psychiatric outpatient clinic at least a year ago, and 1) medication treatment adherence level in the last month, 2) the socio-demographic and clinical characteristics that affect adherence, and 3) the number of follow-up examinations within the last year.

\section{METHOD}

In previous studies, subjective methods such as examining patient records, investigating repeat prescriptions, views of physicians conducting the treatment on adherence, and self-report of patients regarding their drug use and objective methods such as checking serum and drug levels, measuring drug and metabolite levels in blood, saliva, and urine, and counting the remaining pills in the drug bottles were used. All of these methods have their own limitations and negative sides. For example, even though objective methods seem to be preferred, results obtained are not at the desired level due to issues such as the time drugs are taken, the difference in metabolism, the way in which drug levels are measured, and obtaining permission from patients. In addition, some researchers have tried to measure adherence by developing scales based on patient attitude as an alternative to these methods. In terms of determining treatment adherence, some researchers $(10,15)$ define 
not taking $30 \%$ of recommended medication in the last month as nonadherence and partial adherence, and some other researchers define nonadherence as missing at least one dose of recommended medication within the last ten days (1).

The necessary permission and approval was obtained from the Ethics Committee of Inönü University Medical Faculty in order to conduct the study. The sample group of this study comprised of 147 euthymic patients, aged over 18 that had visited the Psychiatry Outpatient Clinic of Malatya State Hospital, and been diagnosed with a bipolar disorder in accordance with DSM-IV, and had been monitored at the clinic for at least a year because of this diagnosis. The purpose of the study was explained to patients, and those that accepted voluntarily to participate in the study were included in the study. Patients that had severe medical conditions other than Bipolar Disorder (uncontrolled endocrinological illnesses, cardiovascular disease, respiratory disorders, and cancer) and patients that were mentally retarded were excluded from the study. Hospital records were examined simultaneously for patients attending their follow-up examinations between February, 01, 2011 and February, 28, 2011. Patients that had computerized records as of February, 01,2010 were included in this study, and their number of follow-up examinations was recorded from hospital records. Information regarding participating patients' demographic variables, clinical properties, and their attitude towards their illness and treatment were recorded in the Data Gathering Form.

The fields for which data was gathered using the Data Gathering Form were age, gender, marital status, education level, place of residence, employment status, social security, demographic data established from economical status, the duration of the illness and the history of mental illness in the family, life style (alone/ living at home), current medications, and the causes of the illness and hospitalizations; the form also consisted of questions regarding the illness and treatment of patients (Do you believe that you have been sufficiently informed about Bipolar Disorder, its treatment, and medication used? Are you suffering from side-effects of the medication? Are you experiencing problems in obtaining your medication due to economical difficulties? Are you experiencing problems in obtaining your medication due to transportation difficulties? Are you not taking your medication due to the negative attitude of others towards drug-use? Are you experiencing issues with treatment due to the family negligence? Are you not taking your medication due to issues with the treatment personnel? Are you not taking your medication because you feel that you have recovered from your illness? Are you not taking your medication because you feel that the medication is useless? Willing to take medication; however not taking medication due to forgetfulness and do they feel discontent towards taking medication?).

Individuals that gave positive answers to two of the statements ("I am ill and I need treatment," "I used to suffer from certain mental complaints, but I am fine now," and "I need to continue with my treatment to make sure that my illness does not recurrence") were paid attention, and identified as having an insight according to their psychiatric clinical examination. The patients were classified in eight groups as not on medication, only antipsychotic users, only lithium users, only anticonvulsant users, two or more mood stabilizers users, mood stabilizers + antipsychotic users, mood stabilizers + antidepressant users, mood stabilizers + antipsychotic + antidepressant users.

Patients were asked the question "How many days have you not taken your medication/medications in the last month" as part of the self-report required to measure the level of medication treatment adherence; in conclusion of their answers, patients were separated into two groups. Those that had not taken their medication or taken it irregularly for less than seven days within the last month were categorized as "treatment adherent," those that had not taken it irregularly between 7 and 14 days were categorized as "partially treatment adherent," and those that had not taken it irregularly for more than 14 days within the last month were categorized as "treatment nonadherent." When analyzing the results for this study, those that fell under the "partially treatment adherent" group were included in the "treatment nonadherent" group. The aim was to clearly identify those that were treatment adherent. In the end, groups that were classified as "treatment adherent" and "treatment nonadherent" according to their treatment adherence in the last month were compared based on their sociodemographic characteristics, clinical characteristics, and the number of follow-up examinations within the last year.

SPSS 16.0 was used for the statistical data analysis. 
Once descriptive analysis was conducted to determine the general characteristics of the sample group, the chi-square test was used to analyze the categorical variables (gender, marital status, education level, place of residence, employment status, social security, economical status, the family history of mental illnesses, the duration of the illness, life style, current medication, hospitalization due to their illness, and questions regarding their illness and treatment) between the "treatment adherent" group and the "treatment nonadherent" group; the t-test was used to compare numerical variables (age, number of follow-up examinations). The accepted significance level was $\mathrm{P}<0.05$.

\section{RESULTS}

For this study, 108 (73.5\%) patients were treatment adherent, while 39 (26.5\%) patients were treatment nonadherent. 77 of the 147 patients were male, and 70 were female. The number of women were higher in the "treatment adherent" group and the number of men were higher in the "treatment nonadherent" group $(\mathrm{p}=0.01)$, (Table 1).There was no difference between the "treatment adherent" and the "treatment nonadherent" group based on age, marital status, place of residence, employment status, economical status, whether they had social security benefits or not, and whether the uninsured had health care or not $(\mathrm{p}>0.05)$, (Table 1). Treatment adherence changed with the education level $(\mathrm{p}<0.001)$. Those with education exceeding primary school (8 years) were more adherent. There was no difference between groups based on the duration of the illness and the family history in mental illnesses ( $\mathrm{p}>0.05)$, (Table 1).

Table 1: A comparison of groups based on their sociodemographic characteristics

\begin{tabular}{|c|c|c|c|c|c|c|}
\hline \multirow{3}{*}{ Age (average) } & \multicolumn{2}{|c|}{ Adherent (n=108) } & \multicolumn{2}{|c|}{ Non-adherent $(n=39)$} & & \\
\hline & \multicolumn{2}{|c|}{$37.26 \pm 23$} & \multicolumn{2}{|c|}{$36.17 \pm 9.77$} & \multicolumn{2}{|c|}{$t=-0.536$} \\
\hline & $\mathbf{n}$ & $\%$ & $\mathbf{n}$ & $\%$ & & \\
\hline \multicolumn{7}{|l|}{ Gender } \\
\hline Female & 63 & 58.3 & 14 & 35.9 & \multirow[t]{2}{*}{$\chi^{2}=5.78$} & \multirow[t]{2}{*}{$p=0.01$} \\
\hline Male & 45 & 41.7 & 25 & 64.1 & & \\
\hline \multicolumn{7}{|l|}{ Marital Status } \\
\hline Married & 61 & 56.5 & 16 & 41.0 & \multirow[t]{3}{*}{$\chi^{2}=5.38$} & \multirow[t]{3}{*}{$p=0.06$} \\
\hline Single & 40 & 37.0 & 16 & 41.0 & & \\
\hline Widowed & 7 & 6.5 & 7 & 18.0 & & \\
\hline \multicolumn{7}{|l|}{ Education Level } \\
\hline Low level of education & 60 & 55.6 & 33 & 84.6 & \multirow[t]{2}{*}{$x^{2}=32.99$} & \multirow[t]{2}{*}{$p<0.001$} \\
\hline High level of education & 48 & 44.4 & 6 & 15.4 & & \\
\hline \multicolumn{7}{|l|}{ Place of residence } \\
\hline City & 73 & 67.6 & 26 & 66.7 & \multirow[t]{3}{*}{$\chi^{2}=0.58$} & \multirow[t]{3}{*}{$p=0.74$} \\
\hline District & 23 & 21.3 & 7 & 17.9 & & \\
\hline Village & 12 & 11.1 & 6 & 15.4 & & \\
\hline \multicolumn{7}{|l|}{ Employment Status } \\
\hline Employed & 48 & 44.4 & 14 & 35.9 & \multirow[t]{2}{*}{$\chi^{2}=1.57$} & \multirow[t]{2}{*}{$p=0.45$} \\
\hline Unemployed & 60 & 55.6 & 25 & 64.1 & & \\
\hline \multicolumn{7}{|l|}{ Economical Status } \\
\hline Good & 12 & 11.1 & 2 & 5.1 & \multirow[t]{3}{*}{$\chi^{2}=1.57$} & \multirow[t]{3}{*}{$p=0.45$} \\
\hline Moderate & 70 & 64.8 & 25 & 64.1 & & \\
\hline Bad & 26 & 24.1 & 12 & 30.8 & & \\
\hline \multicolumn{7}{|l|}{ Life Style } \\
\hline Alone & 12 & 11.1 & 7 & 17.9 & \multirow[t]{2}{*}{$\chi^{2}=0.190$} & \multirow[t]{2}{*}{$p=0.27$} \\
\hline Living at home & 96 & 88.9 & 32 & 82.1 & & \\
\hline \multicolumn{7}{|l|}{ Social Security } \\
\hline Yes & 100 & 92.6 & 33 & 84.6 & $\chi^{2}=2.11$ & $p=0.14$ \\
\hline No & 84.6 & 15.4 & 6 & 15.4 & & \\
\hline $\begin{array}{l}\text { Health card for uninsured } \\
\text { individuals }\end{array}$ & & & & & & \\
\hline Yes & 32 & 29.6 & 16 & 41.0 & $\chi^{2}=1.69$ & $p=0.19$ \\
\hline No & 76 & 70.4 & 23 & 59.0 & & \\
\hline
\end{tabular}




\begin{tabular}{|c|c|c|c|c|c|c|}
\hline & \multicolumn{2}{|c|}{ Adherent $(n=108)$} & \multicolumn{2}{|c|}{ Non-adherent $(n=39)$} & & \\
\hline & n & $\%$ & $\mathbf{n}$ & $\%$ & & \\
\hline \multicolumn{7}{|l|}{ Family history in mental illnesses } \\
\hline Yes & 27 & 25.0 & 10 & 25.6 & $\chi^{2}=0.06$ & $p=0.93$ \\
\hline No & 81 & 75.0 & 29 & 74.4 & & \\
\hline \multicolumn{7}{|l|}{ The cause of the illness and hospitalization } \\
\hline Yes & 35 & 32.4 & 21 & 53.8 & $\chi^{2}=0.190$ & $p=0.27$ \\
\hline No & 73 & 67.6 & 18 & 46.2 & & \\
\hline \multicolumn{7}{|l|}{ The duration of the illness } \\
\hline $0-5$ years & 34 & 31.5 & 13 & 33.3 & $\chi^{2}=0.154$ & $\mathrm{p}=0.98$ \\
\hline $6-10$ years & 30 & 27.8 & 10 & 25.6 & & \\
\hline $11-15$ years & 23 & 21.3 & 9 & 23.1 & & \\
\hline 16 years and above & 21 & 19.4 & 7 & 17.9 & & \\
\hline \multicolumn{7}{|l|}{ Insight } \\
\hline Yes & 96 & 88.9 & 16 & 41.0 & $\chi^{2}=36.185$ & $p<0.001$ \\
\hline No & 12 & 11.1 & 23 & 59.0 & & \\
\hline \multicolumn{7}{|l|}{ Current medication } \\
\hline Not on medication & 0 & 0.0 & 8 & 20.5 & & \\
\hline Antipsychotic & 22 & 20.4 & 5 & 12.8 & $\chi^{2}=0.65$ & $p=0.42$ \\
\hline Lithium & 18 & 16.7 & 3 & 7.7 & $\chi^{2}=1.23$ & $p=0.27$ \\
\hline Anticonvulsant & 7 & 6.5 & 4 & 10.3 & $\chi^{2}=0.17$ & $p=0.67$ \\
\hline $\begin{array}{l}\text { Two or more mood stabilizers } \\
\text { (MS) }\end{array}$ & 15 & 13.9 & 6 & 15.4 & $\chi^{2}=0.007$ & $p=0.97$ \\
\hline MS + Antipsychotic & 40 & 37.0 & 12 & 30.8 & $\chi^{2}=0.21$ & $p=0.62$ \\
\hline MS + Antidepressant & 1 & 7.0 & 0 & 0.0 & $\chi^{2}=1.62$ & $p=0.20$ \\
\hline MS + Antipsychotic + Antidepressant & 5 & 4.6 & 1 & 2.6 & $\chi^{2}=0.005$ & $p=0.54$ \\
\hline No of Follow-Up Examinations / year (average) & & & & & $t=-5.42$ & $p<0.001$ \\
\hline
\end{tabular}

The rate of hospitalization was lower in the treatment adherent group in comparison to the treatment nonadherent group $(\mathrm{p}<0.05)$. There was also a difference between groups based on the number of follow-up examinations attended in the last year. The rate of attending follow-up examinations was higher in the adherent group in comparison to the nonadherent group $(\mathrm{p}<0.001)$. The insight rate patients had towards their illness was significantly higher in the "treatment adherent" group in comparison to the "treatment nonadherent" group $(\mathrm{p}<0.001)$, (Table 2$)$. In terms of current medication or medication combinations, there was no significant difference between the two groups; in other words, adherence was independent from the current medications prescribed $(\mathrm{p}>0.05)$.

The "treatment adherent" group believe that they are more informed about their illness and treatment in comparison to the "treatment nonadherent" group ( $\mathrm{p}<0.001)$. In the "treatment nonadherent" group, the rate of abandoning medication because patients thought the medication was non-effective $(\mathrm{p}<0.05)$ and the rate of abandoning treatment because patients thought they had recovered $(\mathrm{p}<0.001)$ were higher. The rate of abandoning treatment because patients thought they had recovered was higher in comparison to the rate of abandoning treatment because patients thought the medication was non-effective $\left(\mathrm{p}=0.04, \chi^{2}=8.64\right)$. There was no difference between the two groups based on drug side effects, economical difficulties, transportation issues, negative attitude others have towards taking medication, family negligence, experiencing issues with treatment personnel, and forgetfulness ( $p>0.05)$. The number of patients discontent about taking medication was higher in the treatment nonadherent group in comparison to the treatment adherent group $(\mathrm{p}<0.05)$ (Table 3$)$.

\section{DISCUSSION}

In our study, $73.5 \%$ of patients were treatment adherent. According to other subject-related studies, this rate is the expected rate, and it complies with literature. It is an extremely difficult task to determine the rate of treatment 


\section{Adherent $(n=108)$}

\begin{tabular}{|c|c|c|c|c|c|c|}
\hline & $\mathbf{n}$ & $\%$ & n & $\%$ & & \\
\hline \multicolumn{7}{|c|}{$\begin{array}{l}\text { Do you believe that you have been sufficiently } \\
\text { informed about Bipolar Disorder, its treatment, } \\
\text { and medication used? }\end{array}$} \\
\hline Yes & 6 & 5.6 & 15 & 38.5 & $\chi^{2}=25.33$ & $p<0.001$ \\
\hline No & 102 & 94.4 & 24 & 61.5 & & \\
\hline \multicolumn{7}{|c|}{$\begin{array}{l}\text { Are you suffering from side-effects of } \\
\text { the medication? }\end{array}$} \\
\hline Yes & 18 & 16.7 & 9 & 23.1 & $\chi^{2}=0.785$ & $p=0.37$ \\
\hline No & 90 & 83.3 & 30 & 76.9 & & \\
\hline \multicolumn{7}{|c|}{$\begin{array}{l}\text { Are you experiencing problems in obtaining } \\
\text { your medicine due to economical difficulties? }\end{array}$} \\
\hline Yes & 17 & 23.1 & 9 & 23.1 & $\chi^{2}=1.059$ & $p=0.30$ \\
\hline No & 91 & 76.9 & 30 & 76.9 & & \\
\hline \multicolumn{7}{|c|}{$\begin{array}{l}\text { Are you experiencing problems in obtaining } \\
\text { your medicine due to transportation difficulties? }\end{array}$} \\
\hline Yes & 5 & 7.7 & 3 & 7.7 & $\chi^{2}=0.522$ & $p=0.47$ \\
\hline No & 103 & 92.3 & 36 & 92.3 & & \\
\hline \multicolumn{7}{|c|}{$\begin{array}{l}\text { Are you not taking your medication due to } \\
\text { the negative attitude of others towards medication? }\end{array}$} \\
\hline Yes & 4 & 10.3 & 4 & 10.3 & $\chi^{2}=0.310$ & $p=0.57$ \\
\hline No & 35 & 89.7 & 35 & 89.7 & & \\
\hline \multicolumn{7}{|c|}{$\begin{array}{l}\text { Are you experiencing issues with treatment } \\
\text { due to the family negligence? }\end{array}$} \\
\hline Yes & 8 & 7.4 & 2 & 5.1 & $\chi^{2}=0.235$ & $p=0.62$ \\
\hline No & 100 & 92.6 & 37 & 94.9 & & \\
\hline \multicolumn{7}{|c|}{$\begin{array}{l}\text { Are you not taking your medication } \\
\text { due to issues with the treatment personnel? }\end{array}$} \\
\hline Yes & 3 & 2.8 & 1 & 2.6 & $\chi^{2}=0.005$ & $p=0.94$ \\
\hline No & 105 & 97.2 & 38 & 97.4 & & \\
\hline \multicolumn{7}{|c|}{$\begin{array}{l}\text { Are you not taking your medication because you } \\
\text { feel that you have recovered from your illness? }\end{array}$} \\
\hline Yes & 3 & 2.8 & 25 & 64.1 & $\chi^{2}=69.88$ & $p<0.001$ \\
\hline No & 105 & 97.2 & 14 & 35.9 & & \\
\hline \multicolumn{7}{|c|}{$\begin{array}{l}\text { Are you not taking your medication because } \\
\text { you feel that the medication is useless? }\end{array}$} \\
\hline Yes & 4 & 3.7 & 5 & 12.8 & $\chi^{2}=4.144$ & $p=0.04$ \\
\hline No & 104 & 96.3 & 34 & 87.2 & & \\
\hline \multicolumn{7}{|c|}{$\begin{array}{l}\text { Are you not taking your medication } \\
\text { because you forget to take it? }\end{array}$} \\
\hline Yes & 25 & 23.1 & 6 & 15.4 & $\chi^{2}=1.038$ & $p=0.30$ \\
\hline No & 83 & 76.9 & 33 & 84.6 & & \\
\hline \multicolumn{7}{|c|}{ Do you feel discontent about taking medication? } \\
\hline Yes & 29 & 26.9 & 18 & 42.6 & $\chi^{2}=4.908$ & $p=0.027$ \\
\hline No & 79 & 73.1 & 21 & 53.8 & & \\
\hline
\end{tabular}

adherence of patients accurately. There is no consensus on the subject as to what method should be used to assess adherence (18). In their study, Lingam et al. identified that the patient self-report, used to evaluate adherence, was the truest subjective method used. It is reported to be highly specific (90\%), have low level of sensitivity (approx. 50\%). In their study Lingam et al. classified those that had "not taken more than $30 \%$ of their recommended medication in the last month" were treatment nonadherent; in conclusion they indicated that self-report was highly comparable to serum lithium levels, evaluated independently (6). In their self-report study, Scott et al. classified those that "had not taken more than $30 \%$ of their prescribed medication in the last month" were partially treatment nonadherent; they concluded that $68 \%$ of patients were treatment adherent (12). In their study, Baldessarini et al. classified those that 
"had not taken at least one dose of their recommended medication in the last 10 days" as treatment nonadherent; they concluded that $66 \%$ of patients were treatment adherent (1). In their self-report study, Sajatovic et al. classified those that "had not forgotten to take a dose of their medication in the last month" as treatment adherent; they concluded that $61.5 \%$ of patients were treatment adherent (18).

The rate of treatment adherence was higher in women in comparison to men. As well as studies that conclude men are less treatment adherent than women $(6,19,20)$, similar to our study, there are studies that conclude women are less treatment adherent (21), and studies that indicate that gender has no effect on adherence $(5,9,22)$.

The education level, level of insight towards their illness, and the level of information regarding their illness was lower for those in the nonadherent group in comparison to the adherent group. This is an expected result that complies with literature $(1,20,22,23)$. The education level, the insight level, and the knowledge level regarding the illness are all factors that affect adherence. Sajatovic et al. identified that patients with a good level of insight had a better level of knowledge regarding their illness (11). Various studies state that patients informed about the possible results and treatment of their illness are more treatment adherent (24). In their study, Bates et al. determined that patients with a low education level are more treatment nonadherent (21).

The number of follow-up examinations attended, and indirect parameter that indicates treatment adherence, was higher in the "treatment adherent" group. The "treatment adherent" group attended their follow-up examinations more regularly.

There was no difference between the "treatment adherent" and the "treatment nonadherent" group based on age, marital status, place of residence (whether they lived in the city or the countryside), employment status, whether or not they had social security benefits, the duration of the illness, family history of mental illnesses, and hospitalization. Samalin et al. indicated that younger patients were less adherent (20) and Kessing et al. indicated that elderly patients were less adherent. In addition, Kessing et al. indicated that there was a relationship between constant hospitalization and treatment nonadherence (22).

An important point that needs to be touched upon is that treatment adherence was independent of current medications prescribed. There was no difference between the two groups in terms of taking antipsychotic medication, mood stabilizers, taking two or more mood stabilizers together, and taking mood stabilizers and antipsychotic medication together. In our study, there were no patients taking long-acting antipsychotics. A study indicated that in the group of bipolar patients that use classic long-acting antipsychotics the number of times they were hospitalized was lower that the number of follow-up examinations attended (25). As well as preventing relapse of bipolar disorder and preventing the illness from getting worse, long-acting antipsychotics can be an effective instrument in coping with treatment adherence $(20,26)$. In their study, conducted on a nonadherent group, Savaş et al. reported that long-acting risperidone improve progression by restricting relapse (27). El-Mallakh emphasized that long-term effective medication preventing relapse of bipolar disorder was also valuable in patient's treatment adherence (2).

Another important subject is that there was no difference between the two groups based on marital status and whether the patient lived alone or with their family. There are studies that indicate that single patients and patients living alone are less adherent (20).

In terms of abandoning medication, the leading reasons for abandoning medication were that patients believed they had recovered, and they believed that the treatment was useless. In the nonadherent group, the rate of abandoning medication because they believed they had recovered was higher than the rate of abandoning medication because they believed the medication was not doing them any good. In other words, the reason why patients abandoned the medication was due to the fact that they believed they have fully recovered. They may think this way because of their desire to live in a hypomanic or manic state. This, in turn, complies with the "insufficient insight" information indentified in treatment nonadherent patients. Another reason that disrupts adherence is "being discontent with using medication."

The most important limitation of this study is the fact that other comorbid mental disorders were not excluded from the study.

In conclusion of our study, it is possible to state that some factors, such as a lower education level, insufficient information about the illness, lack of insight, being 
discontent about using medication, could be changed by educating patients and their close relatives and these were conditions seen mostly is the nonadherent group. In addition, being discontent about using medication seems to be effective in nonadherence, the reasons behind it should be investigated and remedied.

\section{References:}

1. Baldessarini RJ, Perry R, Pike J. Factors associated with treatment nonadherence among US bipolar disorder patients. Hum Psychopharmacol Clin Exp 2008; 23:95-105.

2. El-Mallakh RS. Medication adherence and the use of long-acting antipsychotics in bipolar disorder. Journal of Psychiatric Practice 2007;13(2):79-85.

3. Üstünsoy Çobanoğlu ZS, Aker T, Çobanoğlu N. Şizofreni ve diğer psikotik bozukluğu olan hastalarda tedaviye uyum sorunları. Düşünen Adam 2003;16:211-218.

4. Sajatovic M, Velligan DI, Weiden, Valenstein MA, Ogedegbe G. Measurment of psychiatric treatment adherence. Journal of Psychosomatic Research 2010;69:591-599.

5. Sajatovic M, Biswas K, Kilbourne AK, Fenn H, Williford W, Bauer MS. Factors associated with prospective long-term treatment adherence among individuals with bipolar disorder. Psychiatric Services 2008;59:753-759.

6. Lingam R, Scott J. Treatment non-adherence in affective disorders. Acta Psychiatr Scand 2002;105:164-172.

7. Kessing LV, Hansen HV, Bech P. Attitudes and beliefs among patients treated with mood stabilizers. Clinical Practice and Epidemiology in Mental Health 2006;2-8.

8. Suppers T, Baldessarini RJ, Faedda GL. Risk of recurrence following discontinuation of lithium treatment in bipolar disorder. Arch Gen Psychiatry 1991;48:1082-1088.

9. Sajatovic M, Ignacio RV, West JA, Cassidy KA, Safavi R, Kilbourne AM, Blow FC. Predictors of nonadherence among individuals with bipolar disorder receiving tratment in a community mental health clinic. Comprehensive Psychiatry. 2009;50:100-107.

10. Scott J. Predicting medication non-adherence in severe affective disorders. Acta Neuropsychiatrica 2000;12:128-130.

11. Sajatovic M, Davies M, Hrouda DR. Enhancement of treatment adherence among patients with bipolar disorder. Psychiatric Services 2004;55:264-269.

12. Scott J, Pope M. Self-reported adherence to treatment with mood stabilizers, plasma levels and psychiatric hospitilization. Am J Psychiatry 2002;159:1927-1929.

13. Jonsdottir H, Opjordsmoen S, Birkenaes A, Engh JA, Ringen PA, Vaskinn A, Aamo TO, Friis S, Andreassen OA. Medication adherence in outpatients with severe mental disorders: relation between self-reports and serum level. Journal of Clinical Psychopharmacology 2010;30:169-175.

14. Sturman ED, Sproule BA. Toward the development of a mood disorders insight scale: modification of Birchwood's psychosis insight scale. J Affect Disord 2003;77:21-30.
15. Colom F, Vieta E, Martinez-Aran A, Reinares M, Benabarre A, Gasto C. Clinical factors associated with treatment noncompliance in euthymic bipolar patients. J Clin Psychiatry 2000;61:549-555.

16. Johnson LS, Fulford D. Development of the treatment attitudes questionnaire in bipolar disorder. J Clin Psychol 2008;64:466-481.

17. Sajatovic M, West JA, Meyer WJ, Cassidy KA, Lamkin N, Calabrase JR, Jenkins JH. Subjective aspects of medication treatment and medication adherence among individuals with bipolar disorder. New Research in Mental Health volüm 18:324-332.

18. Sajatovic M, Bauer MS, Kilbourne AM, Vertrees JE, Williford W. Self-Reported medication treatment adherence among veterans with bipolar disorder. Psychiatric Services 2006;57:56-62.

19. Copeland LA, Zeber JE, Salloum IM. Treatment adherence and illness insight in veterans with bipolar disorder. J Nerv Ment Dis 2008;196:16-21.

20. Samalin L, Charpeaud T, Lorabi O, Liorca PM. Patient perspectives on use of long-acting antipsychotics in bipolar disorder: focus on risperidone injection. Patient Prefer Adherence 2010;4:325-334.

21. Bates JA, Whitehead R, Bolge SC, Kim E. Correlates of medication adherence among bipolar disorder: Results of the bipolar evaluation of satisfaction and tolerability (BEST) study: A nationwide cros-sectional survey. Prim Care Companion J Clin Psychiatry 2010;12:1-10.

22. Kessing LV, Hansen HV, Bech P. Attitudes and beliefs among patients treated with mood stabilizers. Clinical Practice and Epidemiology in Mental Health 2006;2:8.

23. Sajatovic M, Levin J, Fuentes-Cassino E, Cassidy KA, Tatsuoka $\mathrm{C}$, Jenkins $\mathrm{JH}$. Illnes experience and reasons for nonadherence among individuals with bipolar disorder who are poorly adherent with medication. Compr Psychiatry 2011;52:280-287.

24. Swartz M, Swanson J, Hiday V, Borum R, Wagner H, Burns B. Violence and severe mental illness: The effects of substance misuse and non-adherence to medication. Am J Psychiatry 1998;155:226-231.

25. Littlejohn R, Leslie F, Cookson J. Depot antipsychotics in the prophylaxis of bipolar affective disorder. Br J Psychiatry 1994;165:827-829.

26. Basoglu C, Gecici O, Ates MA, Semiz UB, Algül A, Ebrinc S, Cetin M. Efficacy and safety of long-acting injectable risperidone during treatment of manic episode with non-compliance bipolar patients. Neurology Psychiatry and Brain Research 2008;15:39-44.

27. Savas HA, Yumru M, Ozen ME. Use of long-acting risperidon in the treatment of bipolar patients. J Clin Psychopharmacol 2006;26:530-531. 